\title{
Exports from the Brazilian automotive sector to the Southern Common Market: Trade diversion or cost reduction?
}

\author{
André Filipe Zago de Azevedo and Angélica Massuquetti
}

ABSTRACT

The automotive sector is one of the sectors in which trade between MERCOSUR countries has grown most strongly. This article examines the possibility that trade diversion occurred in that sector during the period 1991-2010, assuming that product costs fell as a result of market expansion. The analysis is based on the concepts of "cost reduction" and "trade suppression" coined by Corden (1972), which capture the effects of economies of scale. Indices of regional orientation and revealed comparative advantages are used in combination to assess whether the trade bloc is evolving in line with comparative advantages. The results suggest efficiency gains for automotive-sector products, exports of which from Brazil to MERCOSUR grew more vigorously because the expanded and relatively protected market made it possible to exploit the economies of scale that are characteristic of the automotive industry. University of Vale do Rio dos Sinos (unisinos), Brazil. aazevedo@unisinos.br

Angélica Massuquetti is a professor on the Postgraduate Programme in Economics at the University of Vale do Rio dos Sinos (unisinos), Brazil. angelicam@unisinos.br 


\section{I}

\section{Introduction}

The Southern Common Market (MERCOSUR) was created with the aim of expanding the economic integration of its member countries, particularly by eliminating preferential trade barriers in intra-bloc trade. Through the Treaty of Asunción, signed by Argentina, Brazil, Paraguay and Uruguay on 26 March 1991, the four countries ratified their decision to expand the size of their domestic markets to enhance their integration into the increasingly regionalized international economic system. The automotive sector was one of the most important in the integration process: the flow of intrabloc trade increased considerably, despite the absence of legal arrangements to ensure free trade between its member countries. In 1997, exports to MERCOSUR accounted for almost $50 \%$ of total exports from the Brazilian automotive sector.

From the outset of the integration process, a number of authors have claimed that the growth of trade in the automotive sector between the countries of the bloc would represent trade diversion (Yeats, 1997). As is well known, there is a propensity for economies of scale in the automotive sector (Senhoras, 2005; Casotti and Goldenstein, 2008) and the market expansion resulting from the formation of the trade bloc may have helped raise the competitiveness of production within the group of member countries. On that point, it is important to bear in mind other concepts used in the literature to review the effects of economic blocs in the presence of economies of scale, particularly the "cost reduction" and "trade suppression" effects proposed by Corden (1972).
The main objective of this article is to ascertain whether trade diversion occurred in the MERCOSUR automotive sector owing to the presence of economies of scale, and to propose an alternative analysis based on the concepts suggested by Corden (1972). For that purpose, the 76 six-digit products contained in Chapter 87 of the Harmonized System are analysed, to identify those for which trade flows were reoriented towards the interior of the trade bloc, and analyse the trend of their competitiveness in the period 1991-2010. The degree to which automotive-sector trade is redirected "intrabloc" is evaluated through the regional orientation index (ROI), while competitiveness is measured according to the revealed comparative advantage (RCA) index. Thus, if the automotive-sector products that registered the greatest variation in trade towards the bloc become more competitive, this would imply a reduction in the costs of that sector's products, even when they are subject to a high level of protectionism compared to nOn- MERCOSUR countries.

The article contains six sections, including this introduction. Section II describes the main measures adopted by the bloc in relation to the automotive sector, both to regulate intra-zonal trade and to establish the level of protection with respect to imports from outside the zone. Section III discusses theoretical and empirical issues related to the effects of economic blocs in the presence of economies of scale; and section IV sets out the methodology used. Section V analyses the existence of cost reduction in MERCOSUR through the ROI and RCA indices; and section VI presents final thoughts. 


\section{II}

\section{MERCOSUR and the automotive regime legislation}

The most notable product groups excluded from the MERCOSUR liberalization programme consist of the automotive sector and sugar. ${ }^{1}$ In the initial phase of integration, trade in the automotive sector was regulated through Economic Complementation Agreement (ACE) No. 14, which aimed to establish the common market and promote economic complementation in industry to enhance the competitive capacity of the signatory countries. This agreement, which has been in force since 20 December 1990, was and remains one of the tools of dynamic equilibrium between Argentina and Brazil, and is subject to amendment through additional protocols. In 1994, Decision No. 29 defined three basic elements of the bloc's automotive regime, which were to be adopted in January 2000: (i) total liberalization of intra-zonal trade for automotive sector products; (ii) the common external tariff (CET), and (iii) the absence of domestic incentives that distort competitiveness in the region. The rules governing intra-zonal trade and with respect to imports from outside the bloc are two issues that warrant special attention.

Since its creation, commercial exchange between MERCOSUR members can be characterized as managed trade based on minimum regional contents, trade-balance requirements and conditional entry (IDB, 1996). The liberalization of automotive-sector trade between the MERCOSUR countries has been continually postponed owing to differences of opinion over the regime for this sector; and managed trade has been maintained in its place. In the early 2000s, the blocs Common Automotive Policy was inaugurated, establishing the regulation of intra-zonal trade through the exports deviation coefficient (flex), a mechanism that allows for a given imbalance between the exports of the sector. Between 1 August 2000 and 31 December 2005, trade in the sector's products

\footnotetext{
1 The products of the automotive regime include automobiles, light commercial vehicles of up to 1.5 tonnes, buses and trucks, agricultural and highway machines machines, vehicle parts, chassis with engines, trailers, semi-trailers and parts for production and for the spare parts market. In the case of sugar, a transition period was stipulated of up to 1 January 2001, in which intra-bloc trade will be liberalized, accompanied by measures aimed at eliminating public policies that distort production and the exportation of this product in the bloc. Nonetheless, as of early 2014, trade were still subject to import tariffs.
}

was tariff free pursuant to the 30th Additional Protocol of ACE-14, which allowed for a maximum deviation of $3 \%$ of the volume of trade, which would be increased to $10 \%$ in 2003 . Exports that exceeded the authorized limit would be taxed at $70 \%$ of the CET in the case of all types of vehicles and at $75 \%$ of the CET in the case of vehicle parts. ${ }^{2}$

Nonetheless, the rules were altered again in 2002 through the 31st Additional Protocol to ACE-14, which changed the limits on the volume of trade into dollar values. In 2002, for every dollar exported from Argentina to Brazil, the latter could export two dollars to Argentina without paying the tax quotas, thereby maintaining the quotas specified above in the event of exceeding the defined limit. Little by little, the flex would converge to 2.6 in 2005 , and trade would finally be tariff-free in 2006. Nonetheless, the Argentine authorities insisted on maintaining the limits on free trade through the flex regime, until a more balanced pattern of bilateral trade with Brazil became feasible. Accordingly, in July 2006, the 35th Additional Protocol to ACE-14 was published, and took effect between July 2006 and June 2008, amending the annual coefficient of diversion to 1.95 without the payment of taxes. The penalty for exports exceeding the limit was maintained at $75 \%$ and $70 \%$ of the CET rate in the case of vehicle parts and automobiles, respectively (IDB, 2008).

Following intensive negotiations, in June 2008, the 38 th additional protocol to ACE-14 was approved, setting the start of free intra-bloc trade for July 2013, despite pressure from the Brazilian authorities who wanted a shorter deadline. ${ }^{3}$ The novelty was the establishment of an asymmetric flex: the limit for the trade deficit in the sector was set at 1.95 in the case of Argentina and

\footnotetext{
2 The agreement also set a minimum regional content of $60 \%$ (of parts and pieces) for the product to be exempt from tariffs in bilateral transactions.

3 The ending of managed trade in the automotive sector in MERCOSUR should benefit the Brazilian automotive industry more, the production of which is much larger than that of Argentina. Whereas the Brazilian production trend is upwards between 1991 and 2006, attaining a level of roughly 3 million vehicles in 2006, automobile production in Argentina was much more volatile, attaining a level of around 500,000 vehicles in that year.
} 
2.5 in the case of Brazil. Assuming that the agreement this time will be fulfilled, it will have taken 22 years, from 1991 to 2013, for the provisions of the Treaty of Asunción to be fulfilled.

Apart from the absence of free intra-bloc trade, the degree of protectionism in relation to imports from the automotive sector from other countries has always been high within MERCOSUR. Apart from a short period immediately after its formation, when the limit was $20 \%$, the upper limit of the blocs CET for most products has corresponded to the maximum value allowed by the World Trade Organization (WTO). Thus, since the decade of 2000 , the CET was set at $35 \%$ of vehicles generally, and at $14 \%$ for agricultural machinery and vehicle parts.
Kume and Piani (2005) confirmed the high level of protectionism practised in the bloc's automotive sector, by calculating the nominal and effective protection of the MERCOSUR CET in all sectors of activity in 2006 (see table 1). Products of the automotive sector (automobiles, trucks and buses) enjoyed the highest degree of protection, in both nominal and effective terms. These sectors nominal tariff was $34 \%$, far higher than the average tariff of just $12.4 \%$. Effective protection was even greater, at $124 \%$, whereas the average for all sectors was just $17.2 \%$. Apart from enjoying very high effective protection, the sector has state level tax and financial incentives and, in particular, a federal-level automotive regime.

TABLE 1

MERCOSUR: nominal and effective common external tariff (CET), by activity, 2006 (Percentages)

\begin{tabular}{|c|c|c|c|}
\hline Code & Activity & $\begin{array}{l}\text { Nominal common } \\
\text { external tariff }\end{array}$ & $\begin{array}{l}\text { Effective common } \\
\text { external tariff }\end{array}$ \\
\hline 1 & Agriculture & 3.78 & 2.93 \\
\hline 2 & Mining & 3.95 & 1.72 \\
\hline 3 & Oil and coal & 0.00 & -1.82 \\
\hline 4 & Mineral and metallic products & 11.47 & 13.29 \\
\hline 5 & Iron and steel & 7.98 & 12.55 \\
\hline 6 & Non ferrous metallurgy & 9.78 & 10.28 \\
\hline 7 & Other metallurgical products & 15.80 & 21.25 \\
\hline 8 & Machines and tractors & 13.85 & 14.22 \\
\hline 9 & Electrical Appliances & 15.99 & 19.99 \\
\hline 10 & Electronic equipment & 13.10 & 12.86 \\
\hline 11 & Automobiles, trucks and buses & 33.97 & 123.96 \\
\hline 12 & Other vehicles and parts & 13.81 & 14.22 \\
\hline 13 & Wood and furniture & 10.97 & 13.10 \\
\hline 14 & Cellulose, paper and printing & 11.94 & 12.71 \\
\hline 15 & Rubber & 12.84 & 14.70 \\
\hline 16 & Manufacture of chemicals & 12.83 & 13.91 \\
\hline 17 & Oil refining & 4.58 & 5.33 \\
\hline 18 & Miscellaneous chemical products & 8.80 & 10.62 \\
\hline 19 & Pharmaceutical and perfume products & 10.00 & 9.95 \\
\hline 20 & Plastics & 16.54 & 20.59 \\
\hline 21 & Textiles & 16.39 & 21.77 \\
\hline 22 & Garments & 19.58 & 22.28 \\
\hline 23 & Leather and footwear & 14.23 & 15.75 \\
\hline 24 & Coffee industry & 11.33 & 11.73 \\
\hline 25 & Processing of plant products & 12.09 & 22.17 \\
\hline 26 & Slaughtering of animals & 9.76 & 9.81 \\
\hline 27 & Dairy industry & 15.57 & 16.57 \\
\hline 28 & Sugar & 16.00 & 16.90 \\
\hline 29 & Manufacture of vegetable oils & 8.72 & 9.90 \\
\hline 30 & Beverages and other food products & 15.69 & 23.64 \\
\hline \multirow[t]{5}{*}{31} & Miscellaneous products & 14.38 & 16.10 \\
\hline & Simple average & 12.44 & 17.19 \\
\hline & Minimum & 0.00 & -1.82 \\
\hline & Maximum & 33.70 & 123.96 \\
\hline & Standard deviation & 5.92 & 20.74 \\
\hline
\end{tabular}

Source: H. Kume and G. Piani, “MERcosul: o dilema entre união aduaneira e área de livre-comércio", Brazilian Journal of Political Economy, vol. 25, No. 4, São Paulo, 2005.

MERCOSUR: Southern Common Market. 


\section{III}

\section{Trade diversion or cost reduction: theory and measurement}

Studies on the effects of preferential trade liberalization agreements gained special importance in the 1990s, owing to the proliferation of this type of agreement worldwide. MERCOSUR was no exception, and several authors investigated the effects of the bloc on a series of variables using various methodologies (including Piani, 1998; Negri, 1999; Machado and Cavalcanti, 1999; Tigre and others, 1999; Sarti, 2001; Sica, 2005).

Even before the growth of disputes between MERCOSUR countries, Yeats (1997) compared the ROI and RCA indices in the period 1988-1994, and reached the conclusion that the structure of intra-bloc trade was distorted. The author found signs of trade diversion after the bloc had been formed, in the case of products displaying the fastest growth in the regional orientation of their trade, including those of the automotive sector; and he attributed this to the high tariffs imposed on imports from other countries, which would guarantee a protected market to MERCOSUR producers. This view coincides with the "this market is ours" syndrome proposed by Bhagwati (1993), which argues that the formation of a bloc in an environment in which producers play an important role in the determination of trade policies can lead to an increase in protectionism with respect to countries outside the bloc.

Nonetheless, the analysis performed by Viner (1950), based on the concepts of trade creation and trade diversion, is only applicable to sectors that have perfectly competitive market structures and no Economies of scale. Corden (1972) showed that, apart from the traditional effects described by Viner, the existence of economies of scale in sectors whose market structure involves imperfect competition would generate additional welfare effects. The first consists of "cost reduction" and happens when trade integration leads to an increase in the scale of production. Operating in an expanded market increases the firms' efficiency and lowers their average production costs, as shown in figure 1 .

As can be seen, in the initial equilibrium situation $\left(e_{0}\right)$, there is a precisely calibrated import duty $\left(t=P_{A}-P_{C}\right)$ (in other words, a tariff that prevents imports), which diverts the consumption of a given product in country A towards point $\mathrm{d}_{0}$, supplied by domestic production. With the formation of a customs union between country A and other countries that are less efficient in the production of that product, a common external tariff is established, also precisely calibrated, but below the tariff in force before the trade bloc was formed $\left(\mathrm{P}_{\mathrm{UA}}-\mathrm{P}_{\mathrm{C}}\right)$. In the presence of economies of scale, the expansion of the market owing to the formation of a trade bloc leads to a reduction in the average cost of firms operating in country $\mathrm{A}$, which enables it to lower the import tariff. This produces a new equilibrium $\left(\mathrm{e}_{1}\right)$, in which country A supplies the amount $\mathrm{d}_{2}$ of the product to all countries of the bloc and allocates the amount $\mathrm{d}_{1}$ to domestic consumption It should be noted that, although the foreign country $\mathrm{C}$ is more efficient than country $\mathrm{A}\left(\mathrm{P}_{\mathrm{C}}\right)$, in both situations the precisely calibrated import duty impedes imports. Nonetheless, the expansion of the market in the presence of economies of scale leads to an increase in economic efficiency, which makes it possible to lower the import tariff and the price charged to consumers in country A The welfare gains are represented by areas A and B, which reflect the growth of consumer surplus caused by the drop in prices from $\mathrm{P}_{\mathrm{A}}$ to $\mathrm{P}_{\mathrm{UA}}$. These aspects characterize the "cost reduction" situation proposed by Corden (1972).

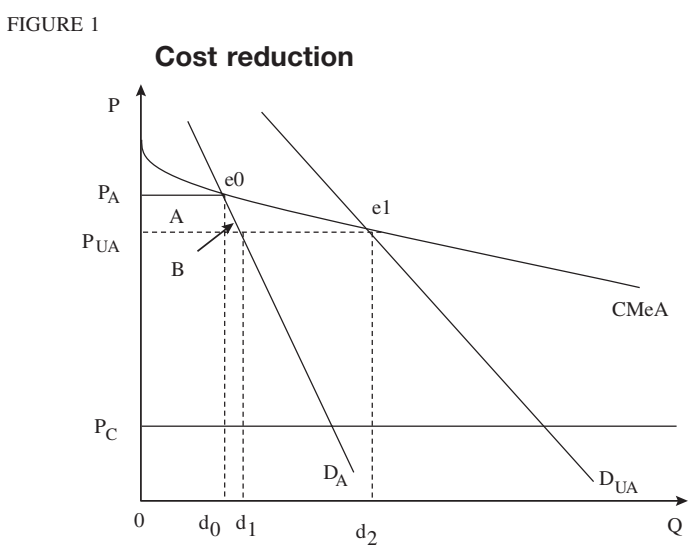

Source: W.M. Corden, "Economies of scale and customs union theory", Journal of Political Economy, vol. 80, No. 3, Chicago, University of Chicago Press, 1972; and A. Panagariya, "The regionalism debate: an overview", World Economy, vol. 22, No. 4, Wiley, 1999. 
The second effect corresponds to "trade suppression", which occurs when the cost reduction arising from integration enables firms operating within the bloc to become more efficient, but not to the extent of supplanting their rivals outside the bloc. The latter happens only thanks to the protectionist measures that the bloc imposes on the more competitive imports from other countries. The new situation is shown in figure 2. In the initial equilibrium $\left(\mathrm{e}_{0}\right)$, the import tariff $\left(\mathrm{t}=\mathrm{P}_{\mathrm{TC}}-\mathrm{P}_{\mathrm{C}}\right)$ is lower than the precisely calibrated tariff, so country A can import $\mathrm{d}_{2}$ from country $\mathrm{C}$ at price $\mathrm{P}_{\mathrm{TC}}$. In that setting, the good in question is not produced in country A and everything that is consumes is imported from country C, which is more efficient. Following the formation of a customs union, a new equilibrium $\left(\mathrm{e}_{1}\right)$ is produced: a precisely calibrated common external tariff is set $\left(\mathrm{P}_{\mathrm{UA}}-\mathrm{P}_{\mathrm{C}}\right)$, at a level above the tariff in force before the formation of the bloc, which leads to an increase in the product's price. As a result of price $\mathrm{P}_{\mathrm{UA}}$, the country starts to produce $\mathrm{d}_{1}$ for domestic consumption and to export $d_{1} d_{3}$. This generates losses owing to the suppression of trade caused by the displacement of an efficient external producer (country C) by a less efficient internal one (country A). In this case, there are welfare losses in terms of both consumer surplus (areas C and D) and government revenues (areas $\mathrm{E}$ and $\mathrm{F}$ ).

The literature refers abundantly to the presence of economies of scale in the automotive sector, characterized by its organization in a global oligopoly, with high gains from economies of scale (Casotti and Goldenstein, 2008; Senhoras, 2005). The presence of economies of scale and agglomeration leads large firms to concentrate in specific geographic regions (Gabriel and others, 2011). The automotive sector is one of the few sectors that display those characteristics in MERCosur (Giordano and Santiso, 1999).

\section{IV}

\section{Methodology}

This article analyses the 76 six-digit-code products contained in Chapter 87 of the Harmonized System, to establish the existence of cost reduction or trade suppression in the MERCOSUR automotive sector in the period 1991-2010. ${ }^{4}$ To that end, the indicators suggested by

${ }^{4}$ The products in Hs Chapter 87 are described in the annex.
FIGURE 2

Trade suppression

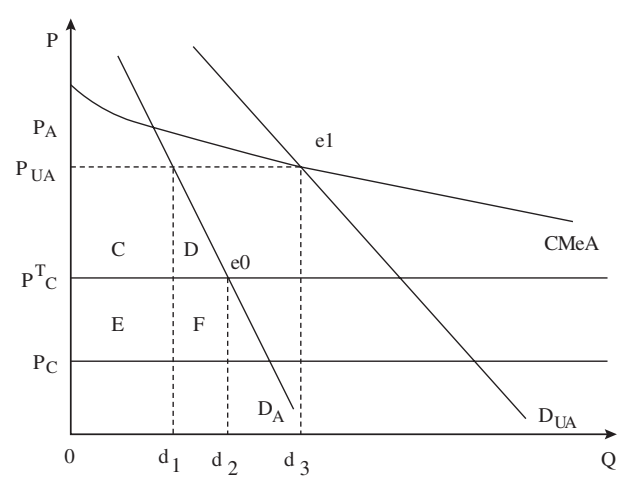

Source: W.M. Corden, "Economies of scale and customs union theory", Journal of Political Economy, vol. 80, No. 3, Chicago, University of Chicago Press, 1972; and A. Panagariya, "The regionalism debate: an overview", World Economy, vol. 22, No. 4, Wiley, 1999.

One way to establish the presence of the two additional effects of economies of scale suggested by Corden (1972) consists of a joint review of the regional orientation index (ROI) and the revealed comparative advantage (RCA) index. A rise in both indices after the formation of the bloc, combined with an increase in the RCA index from a value below one to a value above one, would indicate a situation of "cost reduction". A rise in both indices, without the RCA index reaching the level of 1 , would signal "trade suppression". In both cases, given the prerogative of the existence of economies of scale stemming from an increase in production, the value of exports needs to have increased throughout the period under analysis.

Yeats (1997) are used, but with an interpretation modified by the presence of economies of scale. The analysis of trade orientation uses the ROI, whereas competitiveness is analysed according to the RCA index. The most dynamic products exported by Brazil are identified on the basis of two criteria: (i) the largest absolute variation in the ROI throughout the period analysed, and (ii) a flow of exports to the bloc of at least US\$50,000 at the start of 
the reference period. ${ }^{5}$ Unlike the analysis by Yeats, this article examines the effects of the automotive sector on intra-bloc trade in the framework of a dynamic rather than a static environment, which allows for the influence of economies of scale. Data on Brazilian and world exports of automotive-sector products listed in Chapter 87 of the Harmonized Commodity Description and Coding System (HS) at the six-digit code level, are obtained from the Brazilian Trade and Investment Promotion Agency (Apex-Brasil).

The ROI is a ratio between two proportions, obtained by dividing the share of a given product in a country's total exports to the trade bloc, by that product's share in the total amount exported outside the bloc. The index takes values from zero to infinity, where a value of 1 indicates an equal tendency to export the product in question to countries inside and outside the bloc, whereas rising values and values above one observed through time indicate a propensity to export more to countries inside the bloc. The ROI is defined as follows:

$$
\text { ROI }=(X r j / X t r) /(X o j / X t o)
$$

where:

$X r j=$ value of Brazilian automobile exports within MERCOSUR;

$X t r=$ value of Brazilian exports within MERCOSUR;

$X o j=$ value of Brazilian automobile exports outside MERCOSUR;

Xto $=$ value of Brazilian exports outside MERCosUR.

The RCA index, originally proposed by Balassa (1965), is based on the principle of comparative advantages. It aims to identify the products that a given country "a" produces more competitively than the rest of the world, based on past trade flows of a given product "i" with respect to the total exports of country "a" —in other words, the percentage of product "i" in

5 The minimum level was set to prevent the results being biased towards products with a low share in the export basket at the start of the period under analysis. the country "a" export basket, compared to the total worldwide exports of product " $i$ " in relation to total global exports-. If the RCA index is above 1 , the country has a revealed comparative advantage in exports of the product in question, whereas if it is below 1 , the country displays a revealed comparative disadvantage. A rising index indicates an increase in the competitiveness of the product in country "a" through time. The index is obtained from the following equation:

$$
\operatorname{RCA} j=(X i j / X i) /(X w j / X w)
$$

where:

$X i j=$ value of Brazilian automobile exports;

$X i=$ value of Brazilian exports;

$X w j=$ value of global automobile exports;

$X w=$ value of global exports.

Using the two indices together makes it possible to judge whether the trade bloc evolves according to the comparative advantages of its members after its formation. If the products that are most dynamic in intra-bloc trade (measured through the ROI) are competitive, the bloc would specialize in products in which it is competitive internationally. Nonetheless, if the products that display the fastest growth in ROI are not competitive, the bloc could be diverting trade, probably based on a high protection structure with respect to the rest of the world. When examining sectors characterized by the presence of economies of scale, however, it is necessary also to analyse the trend of the RCA index through time, because market expansion stemming from the creation of a trade bloc could have a positive effect on the production scale of those sectors, thereby increasing their efficiency. ${ }^{6}$

\footnotetext{
${ }^{6}$ According to Yeats (1997), the RCA index has a number of defects. When it is applied to agricultural products, the result of the index could be distorted because it is a sector that is highly influenced by governments, either through export incentives and subsidies or through high tariff and nontariff barriers. In addition, this index does not capture the influence of cyclical factors that could affect the level of exports of the countries at certain times, so sometimes it may be overestimated or underestimated.
} 


\section{Results and analysis}

This section evaluates the orientation and competitiveness of exports from the Brazilian automotive sector to MERCOSUR between 1991 and 2010. Figure 3 reveals the presence of three distinct phases. ${ }^{7}$ The first, from 1991 to 1998 , is marked by a vigorous increase in Brazilian exports to the bloc, which attained a $49 \%$ share of the total in 1997. In the second phase, from 1999 to 2008, was a sharp fall in trade flows, explained by the macroeconomic instability prevailing in the bloc's leading trading partners (Brazilian exchange rate and devaluation and Argentine crisis), which would have a significant effect on the sector. By the end of the period, in 2002, the sector's share in exports to the bloc had dwindled to just $8 \%$. In the last phase, spanning 2003 to 2010, the growth of Brazilian exports to MERCOSUR revived to attain a $56.2 \%$ share, the largest throughout the period analysed.

The methodology described in the foregoing section was used firstly to review the performance of exports to MERCOSUR from the Brazilian automotive sector in the

\footnotetext{
${ }^{7}$ The article only analyses Brazilian exports to the bloc, because these
} represent the sector's largest bilateral trade flow. period 1991-2010. Table 2 lists the 24 products in this sector with six-digit HS codes that display the greatest reorientation of trade towards the bloc according to the ROI and RCA indices. ${ }^{8}$ Comparing these two indicators makes it possible to determine whether the products that showed the greatest reorientation of intra-bloc trade were also competitive. ${ }^{9}$ It should be noted that even at the start of the formation of MERCOSUR, in 1991, the average ROI of those products was above 1. In other words, Brazilian exports were already biased towards the bloc, and this bias increased thereafter, rising from 2.8 to 11.9 between 1991 and 2010 .

Most of the products reporting the greatest variation in the ROI (8) were competitive both in 1991 and in 2010. In the latter year, over half of the products (13) displayed an RCA index above 1 and accounted for $78 \%$

\footnotetext{
${ }^{8}$ It should be noted that, between 1991 and 2010, 39 of the 76 products of chapter posted an increase in the ROI. Nonetheless, just 24 of them also achieve the minimum level of US\$50,000 set for Brazilian exports to MERCOSUR in 1991.

9 Ten of these products belong to the "Vehicle parts and accessories" heading (HS Code 8708) and four belong to "Automobiles for the transport of goods" (Hs Code 8704).
}

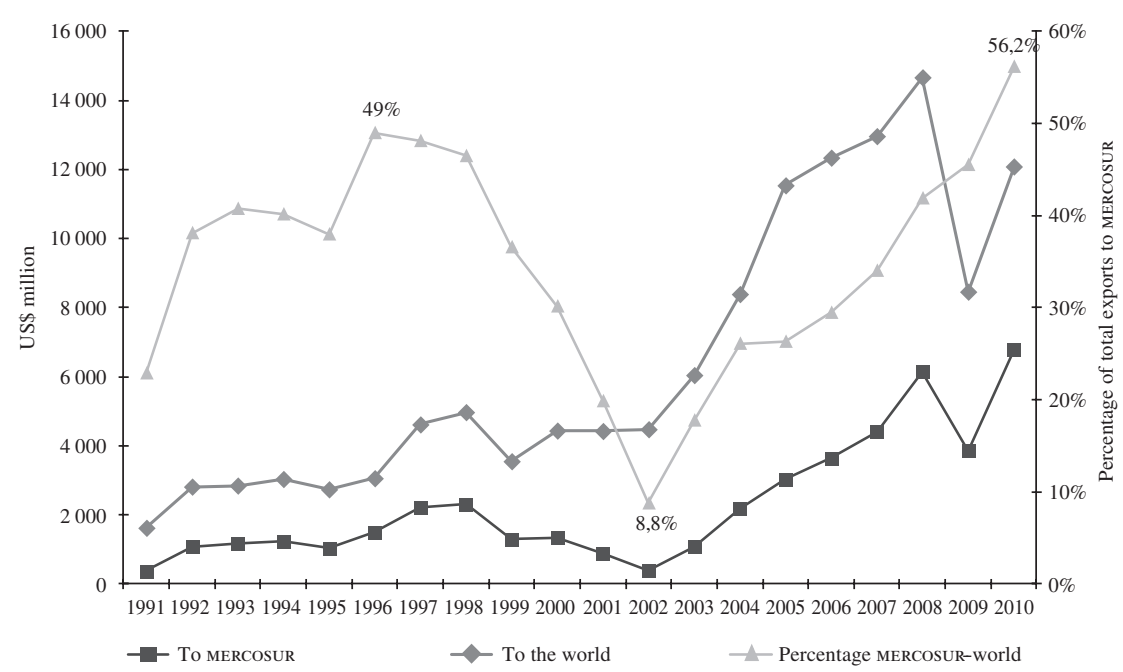

Source: Brazilian Trade and Investment Promotion Agency (APEX-Brasil).

MERCOSUR: Southern Common Market. 
of Brazilian exports of this group of products to the bloc. In other words, when account is taken of the relevance of the sector's products in MERCOSUR internal trade, most of them are considered internationally competitive. For example, the two products with the highest value of exports to the bloc in 2010, namely "Other Vehicles, Spark-ignition Engine of a cylinder capacity exceeding $1,500 \mathrm{cc}$ but not exceeding 3,000 cc for more than six passengers" (Hs Sub-heading 870323) and "Other Vehicles, Spark-ignition Engine of a cylinder capacity exceeding 1,000 cc but not exceeding 1,500 cc for up to six passengers" (HS Sub-heading 870322) not only had an RCA index above 1 in that year, but the index also rose between 1991 and 2010. The table also shows that the aggregate RCA index of all products for which regional orientation increased rose significantly in the period analysed, from 0.59 in 1991 to 1.17 in 2010 .

Accordingly, in contrast to the conclusions reached by Yeats (1997) for the period 1988-1994, the vigorous growth of the automotive sector trade in MERCOSUR between 1991 and 2010 does not seem to have been the result of a trade diversion process. As noted above, in terms of the quantity of products and the representativeness of their trade value, most of the fastest growing Brazilian exports towards the bloc were already internationally competitive or became so during the period reviewed.

Moreover, there was an increase in the RCA index for 14 of the 24 most dynamic products in intra-bloc trade between 1991 and 2010, which suggests that they had become more competitive. That phenomenon, characterized by the increasing competitiveness of automotive sector products could be related to what Corden (1972) called "cost reduction," as discussed in section III.

When the sector is divided into final products and vehicle parts and accessories, there is a significant difference in their importance and trend. Large volumes of Brazilian exports to the bloc consists of final products, particularly in Hs headings 8703 and 8704. Those two groups of products alone accounted for almost two thirds (65.4\%) of Brazil's exports to MERCOSUR in 2010. Moreover, there was an increase in the RCA index for most of those products over the period reviewed. Although numerous products in the parts and accessories group,

TABLE 2

Regional orientation index and revealed comparative advantage index, 1991-2010

\begin{tabular}{|c|c|c|c|c|c|c|c|c|c|}
\hline \multirow{2}{*}{$\begin{array}{l}\text { HS 6-digit } \\
\text { code }\end{array}$} & \multicolumn{2}{|c|}{$\begin{array}{l}\text { Exports to MERCOSUR } \\
\text { (US\$ thousand) }\end{array}$} & \multicolumn{3}{|c|}{ Regional orientation index (ROI) } & \multicolumn{3}{|c|}{$\begin{array}{c}\text { Index of revealed comparative } \\
\text { advantage (RCA) }\end{array}$} & \multirow{2}{*}{$\begin{array}{c}\begin{array}{c}\text { Common } \\
\text { external } \\
\text { tariff }\end{array} \\
2010\end{array}$} \\
\hline & 1991 & 2010 & 1991 & 2010 & Variation & 1991 & 2010 & Variation & \\
\hline 870333 & 979 & 931 & 436.7 & 738.5 & 301.8 & 0.04 & 0.00 & -0.03 & 35 \\
\hline 870421 & 16967 & 411482 & 1.6 & 82.2 & 80.6 & 1.99 & 0.91 & -1.08 & 35 \\
\hline 870850 & 4017 & 265597 & 1.5 & 25.5 & 24.1 & 2.49 & 1.61 & -0.88 & 14 \\
\hline 870892 & 124 & 18365 & 0.6 & 22.8 & 22.2 & 0.20 & 0.28 & 0.09 & 18 \\
\hline 870422 & 13835 & 305734 & 2.6 & 23.1 & 20.4 & 1.40 & 1.87 & 0.47 & 35 \\
\hline 870829 & 3117 & 401315 & 2.7 & 15.4 & 12.7 & 0.13 & 0.95 & 0.83 & 18 \\
\hline 870130 & 56 & 313 & 0.2 & 12.1 & 11.9 & 0.41 & 0.03 & -0.38 & 14 \\
\hline 870323 & 59002 & 2127537 & 6.9 & 18.6 & 11.6 & 0.17 & 1.06 & 0.89 & 35 \\
\hline 870894 & 2429 & 91891 & 2.1 & 13.7 & 11.6 & 1.22 & 0.79 & -0.43 & 18 \\
\hline 870870 & 1960 & 115689 & 0.5 & 10.8 & 10.3 & 2.26 & 1.09 & -1.16 & 18 \\
\hline 870891 & 1321 & 40945 & 2.8 & 12.7 & 9.9 & 0.80 & 0.84 & 0.04 & 18 \\
\hline 870120 & 1347 & 276281 & 1.2 & 9.1 & 7.9 & 0.59 & 1.90 & 1.31 & 35 \\
\hline 870880 & 4904 & 117744 & 3.1 & 9.8 & 6.7 & 1.76 & 1.35 & -0.41 & 18 \\
\hline 871419 & 59 & 5767 & 0.8 & 7.3 & 6.6 & 0.11 & 0.17 & 0.06 & 16 \\
\hline 870893 & 3145 & 68214 & 1.8 & 6.5 & 4.7 & 1.77 & 1.41 & -0.36 & 18 \\
\hline 870810 & 501 & 15803 & 1.7 & 6.1 & 4.4 & 0.26 & 0.51 & 0.24 & 18 \\
\hline 870431 & 24945 & 214821 & 2.8 & 6.7 & 3.8 & 0.80 & 1.71 & 0.91 & 35 \\
\hline 870600 & 5641 & 218081 & 1.1 & 4.1 & 3.1 & 4.71 & 13.24 & 8.53 & 35 \\
\hline 871640 & 653 & 100 & 6.7 & 8.8 & 2.1 & 1.31 & 0.02 & -1.29 & 35 \\
\hline 870322 & 57267 & 668818 & 11.3 & 13.0 & 1.7 & 0.41 & 1.27 & 0.86 & 35 \\
\hline 870423 & 1829 & 62248 & 0.6 & 1.8 & 1.3 & 1.32 & 1.99 & 0.68 & 35 \\
\hline 871120 & 2286 & 50561 & 4.6 & 4.9 & 0.4 & 0.59 & 1.46 & 0.87 & 20 \\
\hline 870210 & 6148 & 27139 & 0.7 & 0.8 & 0.1 & 4.96 & 1.99 & -2.97 & 35 \\
\hline Total & 225627 & 5795371 & 2.81 & 11.94 & 9.1 & 0.59 & 1.17 & 0.58 & 25.5 \\
\hline
\end{tabular}

Source: prepared by the authors, on the basis of data from the Brazilian Trade and Investment Promotion Agency (APEX-Brasil). MERCOSUR: Southern Common Market. 
which include the heading 8708 , posted an increase in their ROI, they only represented $24.6 \%$ of the sector's exports in 2010. Apart from a smaller share in the Brazilian sectoral export basket, the RCA index of most of those products decreased. Thus, given the smaller volume exported and their loss of competitiveness, a reduction in protectionism with respect to those products could stimulate imports at lower prices, thereby further increasing the competitiveness of the sector in terms of final products.

As noted above, 14 of the products reviewed displayed an increase in the RCA index between 1991 and 2010, and consequently could be the subject of the analysis. According to the established criteria, five of them could be characterized as cases of "cost reduction". The total exports of those products grew by $2,204 \%$ in the reference period, with a value rising from US\$ 144.8 million in 1991 to US\$ 3,338 million in 2010. As a result, those categories alone accounted for $57.6 \%$ of the exports of the most dynamic products in intra-bloc trade in 2010. The CET of four of them was $35 \%$ in 2010 , the maximum permitted by MERCOSUR, whereas the CET for fifth product (20\%) also was above average. Apparently, high protectionism with respect to those products may be the main cause of the increase in Brazilian exports to MERCosur. Nonetheless, given the economies of scale and consequent increase in efficiency, the "cost reduction" could have generated welfare gains for the population, which would not occur in the case of trade diversion. The data on the other six products, for which exports amounted to US\$772.2 million in 2010 (equivalent to $13.3 \%$ of the total), would suggest cases of "trade suppression". ${ }^{10}$ Thus, the Brazilian automotive sector subsectors that most increased their exports to the bloc (around 70\% of the value exported by the sector to the bloc in 2010) would have benefited from the existence of economies of scale, which led to an increase in their competitiveness (measured by the RCA) over the period.

Consequently, although the creation of MERCOSUR could be one of the reasons for the greater competitiveness of the most dynamic products in intra-bloc trade, it is not sufficient to do away with a high CET. On that point, Tigre and others (1999) make a more in-depth analysis of the performance of the automobile industry after the entry into force of the first version of the automotive regime. They argue, for example, that MERCOSUR

\footnotetext{
10 The three remaining products (of the 14 mentioned) already had an RCA index above one in 1991, so they do not apply to either of the two situations.
}

played a decisive role in the restructuring of the sector, particularly in Argentina and Brazil. According to those authors, the regional agreement enabled multinational firms, already present in the two countries, to adopt regional specialization strategies that increased intrabloc trade in final products and inputs. The foregoing analysis shows that the increase in trade could be the result of greater efficiency of the firms operating in MERCOSUR (particularly in the case of final products), which benefited from a wider and relatively protected market to exploit the economies of scale characteristic of the automotive sector.

Apart from analysing the period 1991-2010 globally, this article also examines the trend of intrabloc trade and the competitiveness of the automotive sector products that grew most in that trade during three subperiods, corresponding to each of the main phases of trade between members of the bloc. As shown in the foregoing analysis, between 1991 and 1998 there was a major expansion of Brazilian exports from the automotive sector to MERCOSUR, owing to the preferential elimination of the high tariff barriers in force in previous years. As trade within the bloc became more open, there was a sharp trend towards an increase in trade between member countries. Table 3 shows the products at the HS six-digit level for which the regional orientation index (ROI) increased in absolute terms over that period, along with their revealed comparative advantage (RCA) index and their common external tariff (CET). For all products bar one, the CET is above $15 \%$, and in most cases it attains the upper limit of $35 \%$. These percentages are one of the reasons for the accentuated regionalization.

Over the reference period the ROI trended upwards in the case of 25 products, with an average increase of between 1.5 and 6.0. Most of those products also saw their RCA index rise, which reached a level of 20. This reveals a close relation between the growth of trade and the competitiveness of the products in question, which again indicates the presence of economies of scale related to "cost reduction." The average RCA index also rose considerably, from 1.1 in 1991 to 4.9 in 1998. Moreover, apart from not being able to identify the preponderance of products with a propensity to trade diversion in the sector, most of them became more competitive between 1991 and 1998. In 1998, 12 products displayed an RCA index above 1 and represented $80.8 \%$ of Brazilian exports to the bloc from that group. Accordingly, as in the period 1991-2010, the share of the automotive sector's products in intra-bloc trade increased above all in the case of products that were already competitive internationally or which became more so. 
TABLE 3

Regional orientation index and revealed comparative advantage index, 1991-1998

\begin{tabular}{|c|c|c|c|c|c|c|c|c|c|}
\hline \multirow{2}{*}{$\begin{array}{l}\text { HS 6-digit } \\
\text { code }\end{array}$} & \multicolumn{2}{|c|}{$\begin{array}{l}\text { Exports to MERCOSUR } \\
\text { (US\$ thousand) }\end{array}$} & \multicolumn{3}{|c|}{ Regional orientation index (ROI) } & \multicolumn{3}{|c|}{$\begin{array}{c}\text { Index of revealed comparative } \\
\text { advantage (RCA) }\end{array}$} & \multirow{2}{*}{$\begin{array}{c}\begin{array}{c}\text { Common } \\
\text { external } \\
\text { tariff }\end{array} \\
1998\end{array}$} \\
\hline & 1991 & 1998 & 1991 & 1998 & Variation & 1991 & 1998 & Variation & \\
\hline 871200 & 3165 & 1447 & 20.4 & 177.7 & 157.3 & 0.77 & 0.08 & -0.69 & 16 \\
\hline 870422 & 13835 & 310424 & 2.6 & 25.5 & 22.9 & 1.40 & 4.33 & 2.93 & 35 \\
\hline 871620 & 51 & 1764 & 10.1 & 30.0 & 19.9 & 0.13 & 1.16 & 1.03 & 19 \\
\hline 870120 & 1347 & 83495 & 1.2 & 15.4 & 14.2 & 0.59 & 0.96 & 0.37 & 35 \\
\hline 871639 & 433 & 35413 & 3.3 & 13.8 & 10.5 & 0.28 & 1.75 & 1.48 & 35 \\
\hline 870831 & 1056 & 1603 & 2.4 & 12.2 & 9.8 & 0.92 & 0.11 & -0.80 & 0 \\
\hline 870829 & 3117 & 95747 & 2.7 & 10.2 & 7.5 & 0.13 & 0.65 & 0.53 & 35 \\
\hline 870421 & 16967 & 279568 & 1.6 & 8.0 & 6.4 & 1.99 & 2.46 & 0.47 & 35 \\
\hline 870892 & 124 & 6164 & 0.6 & 6.5 & 5.9 & 0.20 & 0.48 & 0.28 & 21 \\
\hline 870894 & 2429 & 20135 & 2.1 & 6.0 & 3.9 & 1.22 & 1.09 & -0.13 & 21 \\
\hline 871680 & 129 & 813 & 4.1 & 7.4 & 3.3 & 0.15 & 0.25 & 0.10 & 19 \\
\hline 870423 & 1829 & 31565 & 0.6 & 3.2 & 2.6 & 1.32 & 1.97 & 0.66 & 35 \\
\hline 871640 & 653 & 900 & 6.7 & 9.0 & 2.4 & 1.31 & 0.40 & -0.90 & 19 \\
\hline 870893 & 3145 & 18433 & 1.8 & 3.6 & 1.8 & 1.77 & 1.85 & 0.08 & 21 \\
\hline 870860 & 1678 & 9482 & 12.7 & 14.3 & 1.6 & 0.24 & 0.61 & 0.37 & 35 \\
\hline 870870 & 1960 & 38326 & 0.5 & 1.9 & 1.4 & 2.26 & 2.54 & 0.29 & 35 \\
\hline 870850 & 4017 & 39652 & 1.5 & 2.9 & 1.4 & 2.49 & 3.44 & 0.95 & 17 \\
\hline 871419 & 59 & 1557 & 0.8 & 2.1 & 1.3 & 0.11 & 0.26 & 0.16 & 35 \\
\hline 870130 & 56 & 1165 & 0.2 & 1.3 & 1.1 & 0.41 & 0.60 & 0.19 & 17 \\
\hline 870839 & 4616 & 44177 & 0.9 & 1.9 & 1.0 & 1.57 & 1.99 & 0.42 & 35 \\
\hline 871690 & 214 & 2371 & 11.1 & 11.9 & 0.8 & 0.04 & 0.14 & 0.10 & 35 \\
\hline 871120 & 2286 & 15479 & 4.6 & 5.0 & 0.5 & 0.59 & 1.31 & 0.72 & 35 \\
\hline 870600 & 5641 & 47639 & 1.1 & 1.4 & 0.4 & 4.71 & 8.56 & 3.85 & 35 \\
\hline 870810 & 501 & 4933 & 1.7 & 2.0 & 0.2 & 0.26 & 0.75 & 0.49 & 35 \\
\hline Total & 67101 & 1091125 & 1.53 & 5.97 & 4.4 & 1.06 & 4.94 & 3.87 & 27.2 \\
\hline
\end{tabular}

Source: prepared by the authors, on the basis of data from the Brazilian Trade and Investment Promotion Agency (APEX-Brasil). MERCOSUR: Southern Common Market.

Despite the postponement of the automotive regime agreements, in this period there was a certain degree of optimism about the growth prospects for intra-bloc trade. Although full liberalization of the sectors in intra-bloc trade had been put off several times, the government had provided for free trade (31st Protocol to ACE-14) so that the firms in the two largest members of the bloc would benefit from the economies of scale provided by regional protectionism in many automotive-sector products.

Nonetheless, the macroeconomic instability caused by external crises (Mexico in 1995, South-east Asia in 1997, Russian Federation in 1998), or domestic problems (Brazilian exchange rate devaluation in 1999 and the Argentine moratorium in 2001) interrupted the most prosperous phase of intra-bloc trade. ${ }^{11}$ The years between 1999 and 2002 were notoriously the most critical period

\footnotetext{
${ }^{11}$ For a more detailed analysis of trade bloc's advances and reversals see Preusse (2001).
}

for MERCOSUR, owing to the disturbances caused by the international financial crises and consequent losses in the regional trade flow. Table 4 calculates the competitiveness and regional orientation indices in this period, which reflect the consequences of the adverse macroeconomic scenario on the Southern Cone automotive sector.

The fact that fewer products saw their RoI rise than in the previous period (1991-1998) and very few of them were competitive, contributed to the shrinking of intra-bloc trade. Only 13 articles displayed an increase in the ROI in the second period, denoting slower growth of regional trade. In turn, 10 of those articles displayed an RCA index below 1 in 2002. The average of this index fell from 1.2 to 0.6 in the reference period, revealing a joint loss of competitiveness among the most dynamic products in intra bloc trade. Production scale is once again important, because Brazilian exports of the products with the greatest trade orientation towards the bloc declined in absolute terms, and total exports shrank from US\$ 366.5 million in 1999 to US\$ 164.3 million in 2002. 
TABLE 4

Regional orientation index and revealed comparative advantage index, 1999-2002

\begin{tabular}{|c|c|c|c|c|c|c|c|c|c|}
\hline \multirow{2}{*}{$\begin{array}{l}\text { HS 6-digit } \\
\text { code }\end{array}$} & \multicolumn{2}{|c|}{$\begin{array}{l}\text { Exports to MERCOSUR } \\
\text { (US\$ thousand) }\end{array}$} & \multicolumn{3}{|c|}{ Regional orientation index (ROI) } & \multicolumn{3}{|c|}{$\begin{array}{c}\text { Index of revealed comparative } \\
\text { advantage (RCA) }\end{array}$} & \multirow{2}{*}{ 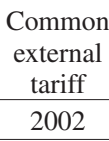 } \\
\hline & 1999 & 2002 & 1999 & 2002 & Variation & 1999 & 2002 & Variation & \\
\hline 871494 & 51 & 8 & 159.5 & 184.1 & 24.6 & 0.02 & 0.00 & -0.02 & 16 \\
\hline 870540 & 272 & 269 & 2.1 & 7.6 & 5.5 & 0.55 & 0.30 & -0.25 & 35 \\
\hline 870421 & 110487 & 49601 & 3.6 & 9.0 & 5.4 & 2.01 & 0.74 & -1.27 & 16 \\
\hline 870840 & 35243 & 27760 & 1.9 & 5.5 & 3.6 & 1.10 & 0.69 & -0.41 & 35 \\
\hline 870332 & 86755 & 29681 & 2.5 & 3.9 & 1.4 & 0.80 & 0.28 & -0.51 & 18 \\
\hline 870810 & 4510 & 1140 & 2.0 & 3.2 & 1.2 & 0.92 & 0.30 & -0.61 & 14 \\
\hline 871492 & 144 & 22 & 3.0 & 4.0 & 1.0 & 0.25 & 0.06 & -0.19 & 35 \\
\hline 870850 & 34712 & 12098 & 3.0 & 3.8 & 0.8 & 3.87 & 2.37 & -1.49 & 18 \\
\hline 870322 & 67821 & 19781 & 1.7 & 2.5 & 0.8 & 1.30 & 0.57 & -0.73 & 20 \\
\hline 870892 & 3405 & 2014 & 6.9 & 7.6 & 0.6 & 0.31 & 0.23 & -0.08 & 16 \\
\hline 870880 & 9197 & 3462 & 1.2 & 1.5 & 0.3 & 2.88 & 1.73 & -1.16 & 35 \\
\hline 870190 & 13760 & 18394 & 2.2 & 2.5 & 0.3 & 0.82 & 1.92 & 1.10 & 18 \\
\hline 870590 & 148 & 140 & 0.5 & 0.5 & 0.0 & 0.12 & 0.24 & 0.12 & 18 \\
\hline Total & 366506 & 164369 & 2.42 & 4.12 & 1.7 & 1.21 & 0.60 & -0.61 & 22.6 \\
\hline
\end{tabular}

Source: prepared by the authors, on the basis of data from the Brazilian Trade and Investment Promotion Agency (APEX-Brasil). MERCoSUR: Southern Common Market.

Consequently, the reorientation of trade that occurred would have been due largely to protectionism. The CET of 12 of the 13 products analysed was above $15 \%$ and attained 35\% in most cases. Moreover, only four of the products with the greatest trade orientation were among most dynamic in the period 1991-1998, which reveals a far-reaching changes in Brazilian exports to MERCOSUR in that crisis period.

As from June 2000, managed trade entered into force between MERCOSUR countries, characterized by the flex system. Moreover, also in this integration phase and owing to the crisis it was going through, the Argentine market was unable to absorb more products manufactured by its own industry and increased its exports to Brazil, even beyond the flex, thereby generating taxed trade as provided for under the established rules.

Once the worst phase of the crisis had passed, the recovery of intra-bloc trade also benefited the automotive sector. As shown in table 5, in the period 2003-2010, 36 products from the automotive sector at the HS six-digit level increased their ROI. Four of those products recorded an absolute variation in the index of more than 100 . While the average ROI of these products grew significantly, from 2.3 in 2003 to 10.9 in 2010, the RCA index remained stable around 1.1. Most of those products (16) saw their RCA index rise, and all of them sharply increased their value exported to the bloc in the period analysed. This indicates a close relationship between the growth of trade and the competitiveness of the products, which in turn signals the exploitation of economies of scale. Three products showed signs of "cost reduction" and eight of "trade suppression." The other products were competitive in 2003 and their RCA indices had risen even more in 2010. Thus, in addition to being unable to identify the preponderance of products with a propensity to trade diversion in the sector, most of them became more competitive between 2003 and 2010.

To summarize, the methodology applied showed that in none of the periods in which trade grew were there clear signs of the predominance of trade diversion; but there were gains associated with the exploitation of economies of scale, particularly in the most protected sectors. In other words, over the period analysed, most automotive-sector products became more competitive, possibly owing to the economies of scale (characterized by an increase in the RCA index). This would represent a situation of "cost reduction" or "trade suppression" according to the concepts defined by Corden (1972) for studying the effects of the formation of country blocs on products that are subject to economies of scale. That intra-bloc performance is partly explained by the fact that the CET of those products is above average. In other words, the high preferences enjoyed by the automotive sector seem to be the main reasons for the reorientation of trade that occurred with respect to the sector's products after the formation of MERCOSUR. Nonetheless, owing to the efficiency gains seen in the products with the greatest reorientation of trade towards the bloc, there are signs of welfare gains for the population from this which contradict the analysis of Yeats (1997). That author established the presence of trade diversion in relation to most of the products whose intra-bloc trade increased, including the automotive sector. 
TABLE 5

Regional orientation index and revealed comparative advantage index, 2003-2010

\begin{tabular}{|c|c|c|c|c|c|c|c|c|c|}
\hline \multirow{2}{*}{$\begin{array}{l}\text { HS 6-digit } \\
\text { code }\end{array}$} & \multicolumn{2}{|c|}{$\begin{array}{l}\text { Exports to MERCOSUR } \\
\text { (US\$ thousand) }\end{array}$} & \multicolumn{3}{|c|}{ Regional orientation index (ROI) } & \multicolumn{3}{|c|}{$\begin{array}{c}\text { Index of revealed comparative } \\
\text { advantage ( } \mathrm{RCA})\end{array}$} & \multirow{2}{*}{$\begin{array}{c}\begin{array}{c}\text { Common } \\
\text { external } \\
\text { tariff }\end{array} \\
2010\end{array}$} \\
\hline & 2003 & 2010 & 2003 & 2010 & Variation & 2003 & 2010 & Variation & \\
\hline 870120 & 42303 & 276281 & 4.2 & 9.1 & 4.9 & 1.21 & 1.90 & 0.68 & 35 \\
\hline 870210 & 2011 & 27139 & 0.2 & 0.8 & 0.6 & 1.88 & 1.99 & 0.11 & 35 \\
\hline 870321 & 18892 & 72707 & 14.0 & 187.4 & 173.4 & 0.54 & 0.50 & -0.03 & 35 \\
\hline 870323 & 262516 & 2127537 & 1.6 & 18.6 & 17.0 & 1.39 & 1.06 & -0.33 & 35 \\
\hline 870331 & 23760 & 65872 & 36.6 & 46.0 & 9.4 & 0.49 & 0.29 & -0.20 & 35 \\
\hline 870333 & 7842 & 931 & 60.4 & 738.5 & 678.1 & 0.06 & 0.00 & -0.06 & 35 \\
\hline 870410 & 235 & 513 & 0.1 & 0.2 & 0.1 & 1.89 & 0.28 & -1.62 & 14 \\
\hline 870421 & 128669 & 411482 & 14.0 & 82.2 & 68.2 & 1.00 & 0.91 & -0.08 & 35 \\
\hline 870422 & 64601 & 305734 & 16.1 & 23.1 & 6.9 & 1.03 & 1.87 & 0.84 & 35 \\
\hline 870423 & 4650 & 62248 & 0.4 & 1.8 & 1.5 & 2.04 & 1.99 & -0.05 & 35 \\
\hline 870431 & 8147 & 214821 & 0.8 & 6.7 & 5.9 & 0.74 & 1.71 & 0.97 & 35 \\
\hline 870710 & 56 & 33 & 0.2 & 1.1 & 0.9 & 0.28 & 0.01 & -0.28 & 35 \\
\hline 870790 & 10994 & 69288 & 0.8 & 2.3 & 1.5 & 6.45 & 6.29 & -0.16 & 35 \\
\hline 870810 & 1569 & 15803 & 1.6 & 6.1 & 4.5 & 0.42 & 0.51 & 0.09 & 18 \\
\hline 870821 & 1132 & 36876 & 10.6 & 117.7 & 107.1 & 0.09 & 1.09 & 1.00 & 18 \\
\hline 870829 & 34291 & 401315 & 4.1 & 15.4 & 11.3 & 0.39 & 0.95 & 0.56 & 14 \\
\hline 870840 & 27639 & 289995 & 3.4 & 12.1 & 8.7 & 0.63 & 0.83 & 0.20 & 18 \\
\hline 870850 & 19197 & 265597 & 4.3 & 25.5 & 21.3 & 2.49 & 1.61 & -0.88 & 14 \\
\hline 870870 & 14129 & 115689 & 1.3 & 10.8 & 9.5 & 1.86 & 1.09 & -0.76 & 14 \\
\hline 870880 & 5436 & 117744 & 1.4 & 9.8 & 8.4 & 1.55 & 1.35 & -0.20 & 18 \\
\hline 870891 & 4397 & 40945 & 1.6 & 12.7 & 11.1 & 1.33 & 0.84 & -0.49 & 18 \\
\hline 870892 & 707 & 18365 & 2.2 & 22.8 & 20.7 & 0.14 & 0.28 & 0.14 & 18 \\
\hline 870893 & 7066 & 68214 & 2.4 & 6.5 & 4.0 & 1.16 & 1.41 & 0.24 & 18 \\
\hline 870894 & 4544 & 91891 & 3.3 & 13.7 & 10.4 & 0.40 & 0.79 & 0.39 & 18 \\
\hline 870899 & 61882 & 268284 & 1.3 & 4.6 & 3.3 & 0.98 & 0.63 & -0.36 & 18 \\
\hline 871120 & 5193 & 50561 & 0.5 & 4.9 & 4.5 & 4.33 & 1.46 & -2.87 & 20 \\
\hline 871491 & 80 & 109 & 9.2 & 26.7 & 17.5 & 0.03 & 0.01 & -0.02 & 16 \\
\hline 871495 & 1187 & 707 & 45.0 & 166.2 & 121.2 & 1.08 & 0.22 & -0.86 & 16 \\
\hline 871496 & 691 & 568 & 249.2 & 300.5 & 51.3 & 0.26 & 0.06 & -0.20 & 16 \\
\hline 871500 & 77 & 21 & 1.0 & 19.0 & 18.0 & 0.11 & 0.00 & -0.11 & 20 \\
\hline 871640 & 201 & 100 & 4.5 & 8.8 & 4.3 & 0.16 & 0.02 & -0.15 & 35 \\
\hline 871690 & 786 & 13589 & 1.8 & 9.4 & 7.6 & 0.19 & 0.37 & 0.18 & 16 \\
\hline Total & 859740 & 6328535 & 2.29 & 10.90 & 8.6 & 1.12 & 1.08 & -0.04 & 24.4 \\
\hline
\end{tabular}

Source: prepared by the authors, on the basis of data from the Brazilian Trade and Investment Promotion Agency (APEX-Brasil). MERCOSUR: Southern Common Market.

\section{VI}

\section{Final thoughts}

The implementation of the common external tariff (CET) in 1995, based on the common MERCOSUR nomenclature (NCM), was a major step towards a common trade policy among the member countries of the bloc. Nonetheless, the degree of protection increased for many products compared to the previous situation, particularly in the automotive sector. Several studies (for example Kume and Piani, 2005) reveal the high level of protectionism of the automotive sector, measured both on the basis of nominal import tariffs, and in terms of effective tariffs. In reality, this sector is one of the most protected in MERCOSUR through the CET. Given the sector's high level of protectionism with respect to countries outside the bloc, there is a possibility that intra-bloc trade grows 
even with respect to non-competitive products, thus raising fears of trade diversion.

Nonetheless, when the possibility of economies of scale is included, the formation of the bloc could be one of the reasons for the greater competitiveness of the automotive sector that are most dynamic products in internal trade, although this is still insufficient to forgo a high CET. The analysis, based on the ROI and RCA indices showed that the growth of trade seems to stem from greater efficiency of firms operating in the bloc, which would benefit from a broader and relatively protected market to take advantage of the economies of scale characteristic of the automotive sector.

Accordingly, an analysis of Brazilian exports to the bloc shows that most of those products seem to have actually suffered from "cost reduction" or "trade suppression" - the concepts coined by Corden (1972) to establish the effects of blocs on sectors in which there are economies of scale- - Although it is true that the dynamism of Brazilian exports to MERCOSUR is partly explained by an above-average CET, the automotive sector was already protected before the trade bloc was created. Although the high preferences of the sector seem to be the main reasons for the regional reorientation of the trade of its products following the formation MERCOSUR, the existence of economies of scale shows the real possibility of welfare gains.

Accordingly, owing to the economies of scale obtained from the expansion of exports from the automotive industry, an intensification of the tariff escalation process already existing in the sector is suggested. Consequently, a high level of protection would be maintained for the final products, particularly those in Headings 8703 and 8704 . Those two groups of products alone represented $65.4 \%$ of Brazilian exports from the automotive sector to MERCOSUR in 2010. In the case of parts and components, particularly those in Heading 8708, a reduction in import tariffs could be allowed, which would stimulate imports at lower prices and further increase the competitiveness of the sector in final products. To conclude, it would be appropriate not only to maintain but also to intensify the tariff escalation process in the MERCOSUR automotive sector. 
ANNEX

\begin{tabular}{|c|c|}
\hline 87.01 & TRACTORS (OTHER THAN TRACTORS OF HEADING 87.09) \\
\hline 8701.10 .00 & Pedestrian controlled tractors \\
\hline 8701.20 .00 & Road tractors for semi-trailers \\
\hline 8701.30 .00 & Track-laying tractors \\
\hline 8701.90 .00 & Other tractors \\
\hline 87.02 & MOTOR VEHICLES FOR THE TRANSPORT OF TEN OR MORE PERSONS, INCLUDING THE DRIVER \\
\hline 8702.10 .00 & With compression-ignition internal combustion piston engine (diesel or semi-diesel) \\
\hline 8702.90 & Other \\
\hline 8702.90 .10 & Trams \\
\hline 8702.90 .90 & Other \\
\hline 87.03 & $\begin{array}{l}\text { MOTOR CARS AND OTHER MOTOR VEHICLES PRINCIPALLY DESIGNED FOR THE TRANSPORT } \\
\text { OF PERSONS (OTHER THAN THOSE OF HEADING 87.02), INCLUDING STATION WAGONS AND } \\
\text { RACING CARS }\end{array}$ \\
\hline \multirow[t]{2}{*}{8703.10 .00} & Vehicles specially designed for travelling on snow; golf cars and similar vehicles \\
\hline & Other vehicles, with spark-ignition internal combustion reciprocating piston engine: \\
\hline 8703.21 .00 & Of a cylinder capacity not exceeding $1,000 \mathrm{cc}$ \\
\hline 8703.22 & Of a cylinder capacity exceeding $1,000 \mathrm{cc}$ but not exceeding $1,500 \mathrm{cc}$ \\
\hline 8703.22 .10 & With capacity to transport up to six persons seated, including the driver \\
\hline 8703.22 .90 & Other \\
\hline 8703.23 & Of a cylinder capacity exceeding 1,500 cc but not exceeding $3,000 \mathrm{cc}$ \\
\hline 8703.23 .10 & With capacity to transport up to six persons seated, including the driver \\
\hline 8703.23 .90 & Other \\
\hline 8703.24 & Of a cylinder capacity exceeding $3,000 \mathrm{cc}$ \\
\hline 8703.24 .10 & With capacity to transport up to six persons seated, including the driver \\
\hline \multirow[t]{2}{*}{8703.24 .90} & Other \\
\hline & Other vehicles, with compression-ignition internal combustion piston engine (diesel or semi-diesel): \\
\hline 8703.31 & Of a cylinder capacity not exceeding $1,500 \mathrm{cc}$ \\
\hline 8703.31 .10 & With capacity to transport up to six persons seated, including the driver \\
\hline 8703.31 .90 & Other \\
\hline 8703.32 & Of a cylinder capacity exceeding 1,500 cc but not exceeding $2,500 \mathrm{cc}$ \\
\hline 8703.32 .10 & With capacity to transport up to six persons seated, including the driver \\
\hline 8703.32 .90 & Other \\
\hline 8703.33 & Of a cylinder capacity exceeding $2,500 \mathrm{cc}$ \\
\hline 8703.33 .10 & With capacity to transport up to six persons seated, including the driver \\
\hline 8703.33 .90 & Other \\
\hline 8703.90 .00 & Other \\
\hline 87.04 & MOTOR VEHICLES FOR THE TRANSPORT OF GOODS \\
\hline \multirow[t]{2}{*}{8704.10 .00} & Dumpers designed for off-highway use \\
\hline & Other, with compression-ignition internal combustion piston engine (diesel or semi-diesel): \\
\hline 8704.21 & Gross vehicle weight (g.v.w.) not exceeding 5 tonnes \\
\hline 8704.21 .10 & Chassis with engine and cabin \\
\hline 8704.21 .20 & With tipper \\
\hline 8704.21 .30 & With refrigeration or isothermic chamber \\
\hline
\end{tabular}


Annex (continuation)

\begin{tabular}{|c|c|}
\hline 8704.21 .90 & Other \\
\hline 8704.22 & g.v.w. exceeding 5 tonnes but not exceeding 20 tonnes \\
\hline 8704.22 .10 & Chassis with engine and cabin \\
\hline 8704.22 .20 & With tipper \\
\hline 8704.22 .30 & With refrigeration or isothermic chamber \\
\hline 8704.22 .90 & Other \\
\hline 8704.23 & g.v.w. exceeding 20 tonnes \\
\hline 8704.23 .10 & Chassis with engine and cabin \\
\hline 8704.23 .20 & With tipper \\
\hline 8704.23 .30 & With refrigeration or isothermic chamber \\
\hline \multirow[t]{2}{*}{8704.23 .90} & Other \\
\hline & Other, with spark-ignition internal combustion piston engine: \\
\hline 8704.31 & g.v.w. not exceeding 5 tonnes \\
\hline 8704.31 .10 & Chassis with engine and cabin \\
\hline 8704.31 .20 & With tipper \\
\hline 8704.31 .30 & With refrigeration or isothermic chamber \\
\hline 8704.31 .90 & Other \\
\hline 8704.32 & g.v.w. exceeding 5 tonnes \\
\hline 8704.32 .10 & Chassis with engine and cabin \\
\hline 8704.32 .20 & With tipper \\
\hline 8704.32 .30 & With refrigeration or isothermic chamber \\
\hline 8704.32 .90 & Other \\
\hline 8704.90 .00 & Other \\
\hline 87.05 & $\begin{array}{l}\text { SPECIAL-PURPOSE MOTOR VEHICLES, OTHER THAN THOSE PRINCIPALLY DESIGNED FOR } \\
\text { THE TRANSPORT OF PERSONS OR GOODS (FOR EXAMPLE, BREAKDOWN LORRIES, CRANE } \\
\text { LORRIES, FIRE FIGHTING VEHICLES, CONCRETE -MIXER LORRIES, ROAD SWEEPER LORRIES, } \\
\text { SPRAYINGLORRIES, MOBILE WORKSHOPS, MOBILE RADIOLOGICAL UNITS) }\end{array}$ \\
\hline 8705.10 .00 & Crane lorries \\
\hline 8705.20 .00 & Mobile drilling derricks \\
\hline 8705.30 .00 & Fire fighting vehicles \\
\hline 8705.40 .00 & Concrete-mixer lorries \\
\hline 8705.90 & Other \\
\hline 8705.90 .10 & Vehicles equipped to determine the characteristic physical parameters (profiling) of oil wells (R. 942/98 MEOSP) \\
\hline 8705.90 .90 & Other \\
\hline 8706.00 & CHASSIS FITTED WITH ENGINES, FOR THE MOTOR VEHICLES OF HEADINGS 87.01 TO 87.05. \\
\hline 8706.00 .10 & For the vehicles of heading 87.02 \\
\hline 8706.00 .20 & For the vehicles of subheadings $8701.10,8701.30,8701.90$ or 8704.10 \\
\hline 8706.00 .90 & Other \\
\hline 87.07 & BODIES (INCLUDING CABS), FOR THE MOTOR VEHICLES OF HEADINGS \\
\hline 8707.10 .00 & For the vehicles of heading 87.03 \\
\hline 8707.90 & Other \\
\hline 8707.90.10 & For the vehicles of subheadings $8701.10,8701.30,8701.90$ or 8704.10 \\
\hline 8707.90 .90 & Other \\
\hline 87.08 & PARTS AND ACCESSORIES OF THE MOTOR VEHICLES OF HEADINGS 87.01 TO 87.05. \\
\hline \multirow[t]{2}{*}{8708.10 .00} & Bumpers and parts thereof \\
\hline & Other parts and accessories of bodies (including cabs): \\
\hline
\end{tabular}


Annex (continuation)

\begin{tabular}{|c|c|}
\hline 8708.21 .00 & Safety seat belts \\
\hline 8708.29 & Other \\
\hline 8708.29 .1 & For the vehicles of subheadings $8701.10,8701.30,8701.90$ or 8704.10 \\
\hline 8708.29 .11 & Mud guards \\
\hline 8708.29 .12 & Radiator grilles \\
\hline 8708.29 .13 & Doors \\
\hline 8708.29 .14 & Instrument panels \\
\hline 8708.29 .19 & Other \\
\hline 8708.29 .9 & Other \\
\hline 8708.29 .91 & Mudguards \\
\hline 8708.29 .92 & Radiator grilles \\
\hline 8708.29 .93 & Doors \\
\hline 8708.29 .94 & Instrument panels \\
\hline \multirow[t]{2}{*}{8708.29 .99} & Other \\
\hline & Brakes and servo-brakes; parts thereof \\
\hline 8708.31 & Mounted brake linings \\
\hline 8708.31 .10 & For the vehicles of subheadings $8701.10,8701.30,8701.90$ or 8704.10 \\
\hline 8708.31 .90 & Other \\
\hline 8708.39 .00 & Other \\
\hline 8708.40 & Gear boxes \\
\hline 8708.40 .10 & For the vehicles of subheadings $8701.10,8701.30,8701.90$ or 8704.10 \\
\hline 8708.40 .90 & Other \\
\hline 8708.50 & $\begin{array}{l}\text { Drive-axles with differential, whether or not provided with other transmission components, and non-driving axles; } \\
\text { parts thereof }\end{array}$ \\
\hline 8708.50.10 & For the vehicles of subheadings $8701.10,8701.30,8701.90$ or 8704.10 \\
\hline 8708.50 .90 & Other \\
\hline 8708.60 & Non-driving axles and parts thereof \\
\hline 8708.60 .10 & For the vehicles of subheadings $8701.10,8701.30,8701.90$ or 8704.10 \\
\hline 8708.60 .90 & Other \\
\hline 8708.70 & Road wheels and parts and accessories thereof \\
\hline 8708.70 .10 & Driving axles of for the vehicles of subheadings $8701.10,8701.30,8701.90$ or 8704.10 \\
\hline 8708.70 .90 & Other \\
\hline \multirow[t]{2}{*}{8708.80 .00} & Suspension systems \\
\hline & Other parts and accessories: \\
\hline 8708.91 .00 & Radiators \\
\hline 8708.92 .00 & Silencers (mufflers) and exhaust pipes \\
\hline 8708.93 .00 & Clutches and parts thereof \\
\hline 8708.94 & Steering wheels, steering columns and steering boxes; parts thereof \\
\hline 8708.94 .1 & For the vehicles of subheadings $8701.10,8701.30,8701.90$ or 8704.10 \\
\hline 8708.94 .11 & Steering wheels \\
\hline 8708.94 .12 & Steering columns \\
\hline 8708.94.13 & Steering boxes \\
\hline 8708.94 .9 & Other \\
\hline 8708.94 .91 & Steering wheels \\
\hline 8708.94 .92 & Steering columns \\
\hline
\end{tabular}


Annex (continuation)

\begin{tabular}{|c|c|}
\hline 8708.94 .93 & Steering boxes \\
\hline 8708.99 & Other parts and accessories \\
\hline 8708.99 .10 & $\begin{array}{l}\text { Accelerator, break, clutch, steering, or gearbox mechanisms, including adaptations of pre-existing models of the type } \\
\text { used by disabled persons (R.1497/98 MEOSP) }\end{array}$ \\
\hline \multirow[t]{2}{*}{87.09} & $\begin{array}{l}\text { WORKS TRUCKS, SELF-PROPELLED, NOT FITTED WITH LIFTING OR HANDLING EQUIPMENT, OF } \\
\text { THE TYPE USED IN FACTORIES, WAREHOUSES, DOCK AREAS OR AIRPORTS FOR SHORT DISTANCE } \\
\text { TRANSPORT OF GOODS; TRACTORS OF THE TYPE USED ON RAILWAY STATION PLATFORMS; PARTS } \\
\text { OF THE FOREGOING VEHICLES }\end{array}$ \\
\hline & Works trucks: \\
\hline 8709.11 .00 & Electrical \\
\hline 8709.19 .00 & Other \\
\hline 8709.90.00 & Parts \\
\hline 8710.00 .00 & $\begin{array}{l}\text { Tanks and other armoured fighting vehicles, motorized, whether or not fitted with weapons, and parts of such } \\
\text { vehicles. }\end{array}$ \\
\hline 87.11 & $\begin{array}{l}\text { MOTORCYCLES (INCLUDING MOPEDS) AND CYCLES FITTED WITH AN AUXILIARY MOTOR, WITH } \\
\text { OR WITHOUT SIDE -CARS; SIDE -CARS }\end{array}$ \\
\hline 8711.10 .00 & With reciprocating internal combustion piston engine of a cylinder capacity not exceeding $50 \mathrm{cc}$ \\
\hline 8711.20 & With reciprocating internal combustion piston engine of a cylinder capacity exceeding $50 \mathrm{cc}$ but not exceeding $250 \mathrm{cc}$ \\
\hline 8711.20 .10 & Motorcycles of a cylinder capacity not exceeding $125 \mathrm{cc}$ \\
\hline 8711.20 .20 & Motorcycles of a cylinder capacity exceeding $125 \mathrm{cc}$ \\
\hline 8711.20 .90 & Other \\
\hline 8711.30 .00 & With reciprocating internal combustion piston engine of a cylinder capacity exceeding $250 \mathrm{cc}$ but not exceeding $500 \mathrm{cc}$ \\
\hline 8711.40 .00 & With reciprocating internal combustion piston engine of a cylinder capacity exceeding $500 \mathrm{cc}$ but not exceeding $800 \mathrm{cc}$ \\
\hline 8711.50 .00 & With reciprocating internal combustion piston engine of a cylinder capacity exceeding $800 \mathrm{cc}$ \\
\hline 8711.90.00 & Other \\
\hline 8712.00 & BICYCLES AND OTHER CYCLES (INCLUDING DELIVERY TRICYCLES), NOT MOTORIZED \\
\hline 8712.00.10 & Bicycles \\
\hline 8712.00.90 & Other \\
\hline 87.13 & $\begin{array}{l}\text { CARRIAGES FOR DISABLED PERSONS, WHETHER OR NOT MOTORIZED OR OTHERWISE } \\
\text { MECHANICALLY PROPELLED }\end{array}$ \\
\hline 8713.10 .00 & Not mechanically propelled \\
\hline 8713.90.00 & Other \\
\hline \multirow[t]{2}{*}{87.14} & PARTS AND ACCESSORIES FOR THE VEHICLES OF HEADINGS 87.11 TO 87.13 \\
\hline & Of motorcycles and motorized tricycles (including mopeds): \\
\hline 8714.11 .00 & Saddles (seats) \\
\hline 8714.19.00 & Other \\
\hline \multirow[t]{2}{*}{8714.20 .00} & Of carriages for disabled persons \\
\hline & Other: \\
\hline 8714.91 .00 & Frames and forks, and parts thereof \\
\hline 8714.92 .00 & Wheel rims and spokes \\
\hline 8714.93 .00 & Hubs, other than coaster braking hubs and hub brakes, and free-wheel sprocket-wheels \\
\hline 8714.94 & Brakes, including coaster braking hubs and parts thereof \\
\hline 8714.94 .10 & Coaster braking hubs \\
\hline 8714.94 .90 & Other \\
\hline 8714.95 .00 & Saddles (seats) \\
\hline 8714.96 .00 & Pedals and pedal mechanisms, and parts thereof \\
\hline 8714.99 .00 & Other \\
\hline
\end{tabular}


Annex (conclusion)

\begin{tabular}{|ll}
\hline 8715.00.00 & BABY CARRIAGES (INCLUDING STROLLERS) AND PARTS THEREOF \\
\hline 87.16 & TRAILERS AND SEMI-TRAILERS FOR ANY VEHICLE; OTHER VEHICLES NOT MECHANICALLY \\
\hline PROPELLED, AND PARTS THEREOF
\end{tabular}

Source: Common MERCOSUR Nomenclature.

Bibliography

Balassa, B. (1965), "Trade liberalization and 'revealed' comparative advantage", The Manchester School of Economic and Social Studies, vol. 33, No. 2.

Bhagwati, J. (1993), "Regionalism and multilateralism: an overview", New Dimensions in Regional Integration, J. De Melo and A. Panagariya (eds.), New York, Cambridge University Press

Casotti, B.P. and M. Goldenstein (2008), "Panorama do setor automotivo: as mudanças estruturais da indústria e as perspectivas para o Brasil", BNDES Setorial, No. 28, Rio de Janeiro, Brazilian Development Bank (BNDES).

Corden, W.M. (1972), "Economies of scale and customs union theory", Journal of Political Economy, vol. 80, No. 3, Chicago, University of Chicago Press.

Gabriel, L.F. and others (2011), "Uma análise da indústria automobilística no Brasil e a demanda de veículos automotores: algumas evidências para o período recente", Anais do $39^{\circ}$ Encontro Nacional de Economia, Rio de Janeiro, National Association of Centers for Post-graduation in Economics (ANPEC).

Giordano, P. and J. Santiso (1999), "La course aux Amériques. Les stratégies des investisseurs européens en Argentine et au Bresil", Études du CERI, No. 52, Paris, Centre for Educational Research and Innovation (CERI).

IDB (Inter-American Development Bank) (1996), Informe Mercosur, No. 1, Buenos Aires [online] http://www.iadb.org/intal/.

(2008), Informe MERCOSUL, No. 1/12, Buenos Aires [online] http://www.iadb.org/intal/.

Kume, H. and G. Piani (2005), "Mercosul: o dilema entre união aduaneira e área de livre-comércio", Brazilian Journal of Political Economy, vol. 25, No. 4, São Paulo.

Machado, J.B. and M.A. Cavalcanti (1999), "Determinantes do comércio bilateral Argentina-Brasil: uma avaliação dos impactos estáticos do processo de integração no MERCOSUL", XXVII Encontro Nacional de Economia, Rio de Janeiro, National Association of Centers for Post-graduation in Economics (ANPEC).
Negri, J.A. (1999), "O custo do bem-estar do regime automotivo brasileiro", Pesquisa e Planejamento Econômico, vol. 29 No. 2, Institute of Applied Economic Research (IPEA).

Panagariya, A. (1999), "The regionalism debate: an overview", World Economy, vol. 22, No. 4, Wiley.

Piani, G. (1998), "Medidas antidumping, anti-subsidios e de salvaguardas: experiência recente e perspectivas no MERCOSUL", Texto para Discussão, No. 541 [online] www.ipea.gov.br/ $\mathrm{pub} / \mathrm{td}$.

Preusse, H. (2001), "MERCOSUR: another failed move towards regional integration?", The World Economy: The Leading Journal on International Economic Relations, vol. 24, Wiley.

Sarti, F. (2001), "Internacionalização comercial e produtiva no mercosul nos anos 90", thesis, Campinas, State University at Campinas.

Senhoras, E.M. (2005), "A industria automobilistica sob enfoque estático e dinâmico: uma análise teórica", VIII SEMEAD, São Paulo, School of Economics, Business and Accounting/ University of São Paulo.

Sica, D. (2005), "La realidad de la industria automotriz ¿en el camino hacia la consolidacion?", Buenos Aires, International Motor Show.

Tigre, P. and others (1999), "Impacto del MERCosur en la dinámica del sector automotor", Impacto sectorial de la integración en el MERCOSUR, J.J. Taccone and L.J. Garay (orgs.), Buenos Aires, Inter-American Development Bank/Institute for Latin American Integration (IDB/INTAL) [online] www.iadb.org/Intal/ aplicaciones/uploads/.

Viner, J. (1950), The Customs Union Issue, New York, Carnegie Endowment for International Peace.

Yeats, A. (1997), "Does MERCosuR's trade performance raise concerns about the effects of regional trade arrangements?", Policy Research Working Paper, No. 1729, Washington, D.C., World Bank. 